\title{
INDEKS MASSA TUBUH REMAJA PUTRI PADA KEJADIAN ANEMIA DI ASRAMA MELANIE SAMARINDA
}

\author{
Yulieta Lehyun Jho'), Maria Floriana Ping'), Elfina Natalia ${ }^{3)}$ \\ ${ }^{1,2,3}$ DIII Keperawatan STIKES Dirgahayu Samarinda J1. Pasundan Nomor 21 \\ Kelurahan Jawa Kecamatan Samarinda Ulu 75122 \\ Email : elfina.natalia@gmail.com
}

\begin{abstract}
Nutrition problems that occur in adolescence is a continuation effect of nutritional problems that occur while still a child. These problems include iron deficiency anemia, underweight and overweight Young women need a lot of iron intake to replace iron lost with blood during menstruation (Sya'bani \& Sumarni, 2016). Anemia is a major health problem in society that is often found throughout the world, especially in developing countries like Indonesia. The world's population with anemia is around $30 \%$ or 2.20 billion people, with most of them living in the tropics. The prevalence of anemia globally is around 51\% (Suryani, Hafiani, \& Junita, 2015). The habits of young women who want to appear slimmer make these teens limit their daily food intake which results in young women being susceptible to anemia (Triwinarni, Hartini, \& Susilo, 2017). This research used descriptive research method, the sampling technique used is non-probability accidental sampling so 32 respondents are involved in this study. The results showed that the data analysis using the Chi Square test was 0.205 at alpha 0.05 . This means that there is no relationship between body mass index with the incidence of anemia in teenagers at Melanie Dormitory Samarinda
\end{abstract}

Keywords: Teenagers, anemia, body mass index

\begin{abstract}
Abstrak
Masalah gizi yang terjadi pada usia remaja merupakan efek kelanjutan dari masalah gizi yang terjadi saat masih anak-anak. Masalah tersebut antara lain anemia defisiensi besi, kekurangan dan kelebihan berat badan Remaja putri memerlukan banyak asupan zat besi untuk mengganti zat besi yang hilang bersama darah selama menstruasi berlangsung (Sya'bani \& Sumarni, 2016). Anemia merupakan masalah kesehatan utama di masyarakat yang sering dijumpai di seluruh dunia, terutama di negara berkembang seperti Indonesia. Penduduk dunia yang mengalami anemia berjumlah sekitar 30\% atau 2,20 miliar orang dengan sebagian besar diantaranya tinggal di daerah tropis. Prevalensi anemia secara global sekitar 51\% (Suryani, Hafiani, \& Junita, 2015). Kebiasaan remaja putri yang ingin tampil langsing menjadikan remaja tersebut membatasi asupan makanan hariannya yang mengakibatkan remaja putri mudah terserang anemia (Triwinarni, Hartini, \& Susilo, 2017). Penelitian ini menggunakan metode penelitian deskriptif, teknik sampling yang digunakan adalah nonprobability accidental sampling sehingga 32 responden dilibatkan dalam penelitian ini. Hasil penelitian menunjukan pada analisis data yang dilakukan menggunakan uji Chi Square di dapatkan hasil 0,205 pada alpha 0,05. Hal ini berarti tidak terdapat hubungan antara Indeks Massa Tubuh dengan kejadian Anemia pada remaja putri di Asrama Melanie Samarinda
\end{abstract}

Kata Kunci: Remaja Putri, anemia, indeks masa tubuh 


\section{PENDAHULUAN}

Usia remaja merupakan usia pertumbuhan anak-anak menuju proses kematangan manusia dewasa. Pada usia remaja, terjadi perubahan pada fisik, biologis, dan psikologis seseorang dan terjadi secara terus-menerus selama usia remaja. Ketidakseimbangan antara asupan dan kebutuhan gizi berakibat pada terjadinya masalah gizi, baik gizi kurang maupun gizi lebih (Briawan, 2013). Masalah gizi yang terjadi pada usia remaja merupakan efek kelanjutan dari masalah gizi yang terjadi saat masih anak-anak. Masalah tersebut antara lain anemia defisiensi besi, kekurangan dan kelebihan berat badan. Kebiasaan makan yang dilakukan semasa remaja akan memberikan dampak terhadap kondisi kesehatan pada fase kehidupan selanjutnya. Remaja putri memerlukan banyak asupan zat besi untuk mengganti zat besi yang hilang bersama darah selama menstruasi berlangsung (Sya'bani \& Sumarmi, 2016). Anemia merupakan masalah kesehatan utama di masyarakat yang sering dijumpai di seluruh dunia, terutama di negara berkembang seperti Indonesia. Kelainan tersebut merupakan penyebab disabilitas kronik yang berdampak besar terhadap kondisi kesehatan, ekonomi, dan kesejahteraan sosial. Penduduk dunia yang mengalami anemia berjumlah sekitar $30 \%$ atau 2,20 miliar orang dengan sebagian besar diantaranya tinggal di daerah tropis. Prevalensi anemia secara global sekitar 51\% (Suryani, Hafiani, \& Junita, 2015).

Kondisi kadar hemoglobin $<12$ gram/dl (pada wanita) dan $<13$ gram/dl (pada pria) dikatakan sebagai kejadian anemia (Udiyono, Saraswati \& Adi, 2017). Anemia merupakan penyebab kecacatan kedua tertinggi didunia. Hal tersebut menjadikan anemia sebagai masalah kesehatan masyarakat yang serius di seluruh dunia. Anemia bisa menyerang siapapun, tak terkecuali remaja yang masih berusia dini. Anemia lebih sering terjadi pada remaja perempuan dibandingkan dengan remaja laki-laki. Hal ini dikarenakan remaja putri kehilangan zat besi (Fe) saat menstruasi sehingga membutuhkan lebih banyak asupan zat besi (Fe). Perilaku remaja putri yang mengkonsumsi makanan nabati lebih banyak mengakibatkan asupan zat besi belum mencukupi kebutuhan zat besi harian. Kebiasaan remaja putri yang ingin tampil langsing menjadikan remaja tersebut membatasi asupan makanan hariannya yang mengakibatkan remaja putri mudah terserang anemia (Triwinarni, Hartini, \& Susilo, 2017). 


\section{METODE PENELITIAN}

Penelitian ini menggunakan metode penelitian deskriptif dengan dua tahap menggunakan alat ukur berupa alat pemeriksaan kadar hemoglobin dan mencari indeks massa tubuh (IMT) dengan mengukur tinggi badan dan berat badan. Teknik sampling yang digunakan adalah non-probability accidental sampling dengan menggunakan kriteria inklusi antara lain: remaja putrid yang tinggal di Asrama Putri Melanie, sudah pernah mengalami menstruasi dan bersedia menjadi responden, sehingga 32 responden dilibatkan dalam penelitian ini.

\section{HASIL DAN PEMBAHASAN}

\section{Analisa Univariat}

Tabel 1. Hasil analisa Uji Univariat kelompok karakteristik responden berdasarkan Indeks Massa Tubuh Remaja Putri

\begin{tabular}{lcc}
\hline \multicolumn{1}{c}{ Karakteristik } & $\mathrm{n}$ & $\%$ \\
\hline kurus $<18,5$ & 13 & 40.6 \\
normal $>18,5-<24,9$ & 16 & 50.0 \\
berat badan lebih $>25,0-<27$ & 1 & 3.1 \\
obesitas $>27,0$ & 2 & 6.3 \\
Total & 32 & 100.0 \\
\hline
\end{tabular}

Berdasarkan tabel 1 menunjukan bahwa responden yang tinggal di Asrama Melanie mayoritas memiliki Indeks Massa Tubuh yang normal yakni sebanyak 16 orang (50\%), dan sebanyak 13 orang ( 40,6\%) memiliki Indeks Massa Tubuh yakni kurus, berat badan lebih sebanyak 1 orang ( $3,1 \%)$, dan obesitas sebanyak 2 orang $(6,3 \%)$ Hasil penelitian menunjukan bahwa responden yang tinggal di Asrama Melanie mayoritas memiliki Indeks Massa Tubuh yang normal yakni sebanyak 16 orang (50 \%). Menurut Adrian dalam Indriani (2017) mengemukakan bahwa status gizi remaja dapat dicerminkan oleh pola makan yang teratur dan aktifitas fisik, agar dapat mencapai pertumbuhan fisik yang optimal. Pertumbuhan status gizi remaja juga dipengaruhi oleh asupan protein, kalori dan energi. Energi yang dibutuhkan oleh remaja sesuai dengan aktifitas yang mereka lakukan, oleh sebab itu apabila tidak sesuai maka kebutuhannya belum tercukupi dengan baik. Dengan mengkonsumsi protein dan kalori sesuai kebuthan dan cukup maka pertumbuhan badan yang menyangkut pertambhan berat badan dan tinggi badan akan dicapai dengan baik (Dieny, 2014).

Tabel 2. Hasil analisa Uji Univariat kelompok karakteristik responden berdasarkan kejadian Anemia pada Remaja Putri

\begin{tabular}{lcc}
\hline Karakteristik & N & Persentase \\
\hline HB Rendah $(<12 \%)$ & 15 & 46.9 \\
HB Normal $(>12 \%)$ & 17 & 53.1 \\
& 32 & 100.0 \\
\hline
\end{tabular}

Berdasarkan tabel 2 menujukan bawa mayoritas responden di Asrama Melanie memiliki hasil tes $\mathrm{Hb}$ yang 
normal sebanyak 17 orang( 53,1\%), sedangkan sebanyak 15 orang $(46,9 \%)$ menunjukan hasil pemeriksaan $\mathrm{Hb}$ rendah. Berdasarkan penelitian menujukan bawa mayoritas responden di Asrama Melanie memiliki hasil tes $\mathrm{Hb}$ yang normal sebanyak 17 orang ( 53,1\%), sedangkan sebanyak 15 orang $(46,9 \%)$ menunjukan hasil pemeriksaan $\mathrm{Hb}$ rendah. kejadian anemia pada remaja putri dapat disebabkan oleh beberapa faktor salah satunya karena status gizi. Dimana status gizi mempunyai korelasi positif dengan konsentrasi Hemoglobin, artinya semakin buruk status gizi seseorang maka semakin rendah kadar Hemoglobinnya (Proverawati, 2011)

\section{Analisa Bivariat}

Tabel 3. Hubungan Indeks Massa Tubuh (IMT) dan kejadian anemia pada

Remaja Putri

\begin{tabular}{|c|c|c|c|c|c|}
\hline $\begin{array}{l}\text { Karakt } \\
\text { eristik }\end{array}$ & Variabel & $\begin{array}{l}\text { Kadar } \\
\text { Hemog } \\
\text { HB } \\
\text { rendah }\end{array}$ & $\begin{array}{l}\text { in } \\
\text { HB } \\
\text { normal }\end{array}$ & Total & $\begin{array}{l}P \\
\text { val } \\
\text { ue }\end{array}$ \\
\hline \multirow{5}{*}{$\begin{array}{l}\text { Kurus } \\
<18,5\end{array}$} & $\mathrm{n}$ & 8 & 5 & 13 & \multirow{7}{*}{$\begin{array}{l}0,2 \\
05\end{array}$} \\
\hline & IMT & $61.5 \%$ & $38.5 \%$ & $\begin{array}{l}100.0 \\
\%\end{array}$ & \\
\hline & $\begin{array}{l}\text { Kadar } \\
\text { hemoglobi } \\
\text { n }\end{array}$ & $53.3 \%$ & $29.4 \%$ & $\begin{array}{l}40.6 \\
\%\end{array}$ & \\
\hline & Total & $25.0 \%$ & $15.6 \%$ & $\begin{array}{l}40.6 \\
\%\end{array}$ & \\
\hline & $\mathrm{n}$ & 6 & 10 & 16 & \\
\hline \multirow{2}{*}{$\begin{array}{l}\text { Norma } \\
1>18,5 \\
-<24,9\end{array}$} & $\begin{array}{l}\% \text { Indeks } \\
\text { Masa } \\
\text { Tubuh }\end{array}$ & $37.5 \%$ & $62.5 \%$ & $\begin{array}{l}100.0 \\
\%\end{array}$ & \\
\hline & $\begin{array}{l}\% \text { Kadar } \\
\text { Hemoglobi } \\
n\end{array}$ & $40.0 \%$ & $58.8 \%$ & $\begin{array}{l}50.0 \\
\%\end{array}$ & \\
\hline
\end{tabular}

\begin{tabular}{|c|c|c|c|c|c|}
\hline \multirow{3}{*}{$\begin{array}{l}\text { Karakt } \\
\text { eristik }\end{array}$} & \multirow{2}{*}{ Variabel } & \multicolumn{2}{|c|}{$\begin{array}{l}\text { Kadar } \\
\text { Hemoglobin }\end{array}$} & \multirow{2}{*}{ Total } & \\
\hline & & $\begin{array}{l}\mathrm{HB} \\
\text { rendah }\end{array}$ & $\begin{array}{l}\text { HB } \\
\text { normal }\end{array}$ & & $\begin{array}{l}\text { val } \\
\text { ue }\end{array}$ \\
\hline & $\%$ Total & $18.8 \%$ & $31.3 \%$ & $\begin{array}{l}50.0 \\
\%\end{array}$ & \\
\hline \multirow{5}{*}{$\begin{array}{l}\text { Berat } \\
\text { badan } \\
\text { lebih }> \\
25,0- \\
<27\end{array}$} & $\mathrm{n}$ & 1 & 0 & 1 & \\
\hline & $\begin{array}{l}\% \text { Indeks } \\
\text { Masa }\end{array}$ & $100.0 \%$ & $0.0 \%$ & $\begin{array}{l}100.0 \\
\%\end{array}$ & \\
\hline & $\begin{array}{l}\text { \% Kadar } \\
\text { Hemoglobi }\end{array}$ & $6.7 \%$ & $0.0 \%$ & $3.1 \%$ & \\
\hline & $\%$ Total & $3.1 \%$ & $0.0 \%$ & $3.1 \%$ & \\
\hline & $\mathrm{n}$ & 0 & 2 & 2 & \\
\hline \multirow{3}{*}{$\begin{array}{l}\text { Obesit } \\
\text { as }> \\
27,0\end{array}$} & $\begin{array}{l}\text { \% Indeks } \\
\text { Masa } \\
\text { Tubuh }\end{array}$ & $0.0 \%$ & $\begin{array}{l}100.0 \\
\%\end{array}$ & $\begin{array}{l}100.0 \\
\%\end{array}$ & \\
\hline & $\begin{array}{l}\% \text { Kadar } \\
\text { Hemoglobi } \\
n\end{array}$ & $0.0 \%$ & $11.8 \%$ & $6.3 \%$ & \\
\hline & $\%$ of Total & $0.0 \%$ & $6.3 \%$ & $6.3 \%$ & \\
\hline
\end{tabular}

Hasil penelitian menunjukan pada analisis data yang dilakukan menggunakan uji Chi Square di dapatkan hasil 0,205 pada alpha 0,05. Hal ini berarti tidak terdapat hubungan antara Indeks Massa Tubuh dengan kejadian Anemia pada remaja putri di Asrama Melanie Samarinda. Hal ini sejalan dengan penelitian yang dilakukan oleh Indriani (2017) yang mengatakan bahwa tidak ada hubungan antara status gizi dengan kejadian anemia pada remaja putri. Pembentukan haemoglobin $(\mathrm{Hb})$ sangat dipengaruhi dan sangat tergantung cukup tidaknya asupan zat gizi lain seperti protein, zat besi dan vitamin $\mathrm{C}$, hal ini sesuai dengan pendapat Darwin Karyadi dalam Mariana (2013) yang menyatakan bahwa konsumsi zat gizi dari 
makanan diharapkan seimbang dalam kandungan zat gizinya, sehingga proses metabolisme tubuh akan bekerja dengan optimal. Sebaliknya apabila salah satu zat gizi tidak terpenuhi, maka metabolisme tubuh tidak dapat bekerja dengan optimal pula. Kebanyakan dari remaja lebih suka mengkonsumsi junk food dan fast food. Makanan dengan kandungan nutrisi dan mineral yang sangat rendah, tinggi garam, lebih banyak lemak dan gula, makanan ini biasanya menghilangkan nafsu makan pada makanan bergizi lain. Makanan ringan memenuhi bagian yang harusnya dipenuhi oleh zat gizi lain dalam satu hari, keadaan ini dapat menyebabkan status gizi seseorang normal namun belum tentu tidak mengalami anemia. Responden dalam penelitian ini adala para remaja putri yang tinggal di Asrama, dimana kebutuhan makanan mereka sungguhsungguh diperhatikan oleh Pembina Asrama, sehingga nutrisi makanan mereka terjamin.

Menurut Tarwoto (2010) dalam Hasyim, Mutalazimah dan Muwakhidah (2018) anemia dapat dicegah dengan tiga pendekatan, antara lain konsumsi tablet tambah darah sebelum dan sesudah menstruasi, pendidikan kesehatan tentang pencegahan anemia serta memperkaya zat besi. Pada remaja putri kehilangan zat besi juga dapat terjadi karena menstruasi (Iragashi et al, 2012 dalam Hasyim, Mutalazimah dan Muwakhidah (2018) maka selanjutnya diharapkan dapat dilakukan penelitian yang lebih komprehensif terhadap faktor yang dapat mempengaruhi kejadian anemia pada remaja putri.

\section{SIMPULAN}

Berdasarkan hasil penelitian yang dilaksanakan pada remaja putri yang tinggal di Asrama Melanie Samarinda ditemukan bahwa:

1. Mayoritas responden yakni sebanyak 16 orang (50\%) memiliki IMT normal, dan sebanyak 13 orang ( 40,6\%) memiliki Indeks Massa Tubuh yakni kurus, berat badan lebih sebanyak 1 orang ( $3,1 \%)$, dan obesitas sebanyak 2 orang $(6,3 \%)$.

2. Mayoritas responden yakni sebanyak sebanyak 17 orang $(53,1 \%)$ memiliki HB normal atau tidak Anemia,sedangkan sebanyak 15 orang $(46,9 \%)$ menunjukan hasil pemeriksaan $\mathrm{Hb}$ rendah atau mengalami kejadian Anemia.

3. Tidak ada hubungan yang erat antar status gizi melalui pengukuran Indeks Massa Tubuh dengan Kejadian Anemia pada remaja putri 
yang tinggal di Asrama Melanie Samarinda.

\section{UCAPAN TERIMA KASIH}

Peneliti mengucapkan terima kasih kepada pihak LPPM dan institusi STIKES Dirgahayu yang telah memberi kesempatan untuk melaksanakan penelitian ini dan memberikan dukungan baik sarana maupun prasarana sehingga peneliti dapat menyelesaikan penelitian ini. Peneliti pun mengucapkan limpah terima kasih kepada responden serta pihak Asrama Melanie Samarinda yang telah terlibat aktif dalam penelitian ini.Semoga penelitian ini memberikan manfaat bagi semua pihak yang terlibat serta menjadi salah satu Evidence Based Learning yang mumpuni dalam dunia pendidikan.

\section{DAFTAR PUSTAKA}

Almatsier, S (2009). Prinsip Dasar Ilmu Gizi. Jakarta: Gramedia Pustaka Utama

Arisman (2007) Gizi Dalam Daur Kehidupan. Buku Ajar Ilmu Gizi. Jakarta: EGC

Briawan, D. (2013). Anemia masalah gizi pada remaja wanita. Jakarta: EGC

Dieny, F. (2014). Permasalahan Gizi pada Remaja Putri. Yogyakarta : Graha Ilmu

Fatmah (2009) Anemia Gizi dan Kesehatan Masyarakat. Jakarta: Raja Grafindo Persada

Indriani,Aisyah (2017) Hubungan Status Gizi Dengan Kejadian Anemia Pada
Remaja Putri di SMAN 1 Kasihan. Jurnal unisayogya

Iragashi, T., Itoh, Y., Maeda, M. (2012). MeanHemoglobin Levels in Venous BloodSamples and Prevalence of Anemia inJapanese Elementary and Junior High

School Students. Journal Nippon Medical School, 79(3).

Mariana,Wina \& Khafidhoh,Nur (2013) Hubungan Status Gizi Dengan Kejadian Anemia Pada Remaja Putri di SMK Swadaya Wilayah Kerja Puskesmas Karangdoro Kota Semarang Tahun 2013. JURNAL KEBIDANAN Vol. 2 No. 4 April 2013 ISSN.2089-7669

Priyanto,D. (2018) Hubungan Umur, Tingkat Pendidikan, dan Aktivutas Fisik Santriwati Husada Dengan Anemia. Jurnal Berkala Epidemologi. Volume 6 Nomor 2 (2018) 139-146

Proverawati, Atikah. 2011. Anemia dan Anemia Kehamilan. Yogyakarta: Nuha Medika

Suryani D, , Hafiani R, Junita R. 2016. Analisis Pola Makan dan Anemia Gizi Besi pada Remaja Putri Kota Bengkulu. Bengkulu. Jurnal Kesehatan Masyarakat Andalas. Vol.10, No. 1, Hal 11-18

Sya'bani, I. R. N., \& Sumarmi, S. (2016). Hubungan status gizi dengan kejadian anemia pada santriwati di Pondok Pesantren Darul Ulum Peterongan Jombang. Jurnal Keperawatan Muhammadiyah, 1(1), $7-15$

Tarwoto. (2010). Kesehatan Remaja Problem dan Solusinya. Jakarta: Salemba Medika.

Triwinarni, C., Hartini, T. N. S., \& Susilo, J. (2017).Hubungan status gizi dengan kejadian anemia gizi besi (AGB) pada siswi SMA di Kecamatan Pakem. Jurnal Nutrisia, 19(1), 61-67 
Mahakam Nursing Journal Vol 2, No. 7, Mei 2020 : 305 - 310

Udiyono, Ari, Aulia, Ghea Yanna, Saraswati, Lintang D.M, Adi, M.S .(2017). Gambaran Status Anemia Pada Remaja Putri di Wilayah Pegunungan dan Pesisir Pantai
(Studi di SMP Negeri Kecamatan Getasan dan Semarang Barat). Jurnal Kesehatan Masyarakat (e-journal) volume 5 nomor 1 http://ejournals1.undip.ac.id/index.php/jkm. 